\title{
JOB RESOURCES AS A MEDIATOR BETWEEN MANAGEMENT TRUST CLIMATE AND EMPLOYEES' WELL-BEING: A CROSS-SECTIONAL MULTILEVEL APPROACH
}

\author{
Michelle Lee Chin Chin ${ }^{1 *}$ and Mohd Awang Idris ${ }^{2}$ \\ ${ }^{1}$ Department of Anthropology and Sociology, University of Malaya, \\ 50603 Kuala Lumpur, Malaysia \\ ${ }^{2}$ School of Psychology, University of Adelaide, 5005, South Australia, Australia \\ Current affiliation: \\ ${ }^{1}$ Department of Psychology, Sunway University, 47500 Petaling Jaya, Malaysia \\ ${ }^{2}$ Department of Anthropology and Sociology, University of Malaya, \\ 50603 Kuala Lumpur, Malaysia \\ *Corresponding author: michellel@sunway.edu.my
}

Published online: 29 December 2017

To cite this article: Lee, M.C.C. and Idris, M.A. (2017). Job resources as a mediator between management trust climate and employees' well-being: A cross-sectional multilevel approach. Asian Academy of Management Journal, 22(2), 27-52. https://doi.org/10.21315/ aamj2017.22.2.2

To link to this article: https://doi.org/10.21315/aamj2017.22.2.2

\begin{abstract}
Adopting the notion that environmental factors affect employees, we investigated the importance of management trust climate as a precursor to job resources (i.e., personal development), positive work outcomes (engagement and job performance) and better well-being (i.e., avoidance of burnout and sleeping problems). Because the Malaysian society is considered to have a higher level of trust than other Asian countries, we used a snowball sampling method and recruited 377 employees from 44 private organisations (62\% response rate) in Malaysia as participants in the current study. Multilevel analyses revealed that management trust climate led to higher levels of personal development and job performance; however, it showed no relation to sleeping problems. In addition, personal development mediated management trust climate and job performance, whereas engagement mediated personal development and job performance. Higher burnout led to increased sleeping problems. This study showed organisational level to be an antecedent of job resources and its job resource-engagement model. Since trust conveys a soft psychological contract between two parties, organisations should be aware of the ways

(C) Asian Academy of Management and Penerbit Universiti Sains Malaysia, 2017. This work is licensed under the terms of the Creative Commons Attribution (CC BY) (http://creativecommons. org/licenses/by/4.0/).
\end{abstract}


trust can be cultivated within the organisation, such as by allowing employees to grow and develop their skills. This may be an effective strategy for ensuring that employees are able to grow within their organisations and execute their duties effectively, without reprisals from higher management.

Keywords: management trust, personal development, job performance, multilevel, Malaysia

\section{INTRODUCTION}

Employees are key contributors to organisational performance and success (Taris \& Schreurs, 2009). However, these contributions are not without challenges. For example, USD240 billion in productivity is lost every year because of healthrelated costs (Mattke, Balakrishnan, Bergamo, \& Newberry, 2007). Loeppke et al. (2009) proposed that management plays a significant role in reducing this number and restoring real productivity. One of the ways management can do this is by instilling a positive trust climate within the organisation.

The concept of trust climate has been extensively used to explore the mutual relation between organisations and employees. Researchers have discovered that trust plays an important role in boosting employees' well-being, job performance, organisational citizenship behaviours, and job satisfaction (Colquitt, Scott, \& LePine, 2007; Daley \& Pope, 2004; Luria, 2009; Scott, 1995; Westin, 2003). Studies have also shown that trust between organisations and employees leads to better work outcomes as it enables employees to stay focused on their tasks and grasp the opportunity to learn (Li, Wang, \& Lim, 2009; Shelton, 2002). In general, trust is defined as the "willingness to increase one's resource investment in another party, based on positive expectation, resulting from past positive mutual interactions" (Tzafrir \& Dolan, 2004, p. 126). In other words, it refers to the mutual interaction between employees and employers in completing their tasks. This suggests that when there is trust, management is more likely to increase its resources and help their employees develop and become more productive.

Unfortunately, although ample evidence has confirmed the relation between trust and employees' outcomes (Aryee, Budhwar, \& Chen, 2002; Mayer \& Gavin, 2005), most of these studies were conducted in Western contexts, with scarce focus on Eastern contexts (Li \& Yan, 2009). Studies in Eastern contexts are crucial since Eastern countries are largely collectivistic and are generally considered to have lower levels of management trust than do Western countries (Huff \& Kelley, 2003). While the concept of organisational trust has been discussed in several previous 
studies, the majority of them have only focused on horizontal trust climate (i.e., employee-employee trust), rather than vertical trust climate (employer-employee trust) (Ferres, Connell, \& Travaglione, 2004). Hence, to fill in this research gap, the present study investigates the mechanism underlying how management trust may influence job performance and health problems, particularly through the motivational and health erosion processes indicated in the job demands-resources (JD-R) model (Bakker \& Demerouti, 2007). We propose that personal development is an area of job resources initiated by management that enables employees to become more competent at work (Akkermans, Schaufeli, Brenninkmeijer, \& Blonk, 2013). Specifically, we propose that a strong trust climate reflects management's initiative in providing more resources to help employees develop, thus making the employees more productive and improving their well-being.

Although Asian countries are viewed as being collectivistic and low in trust, Malaysia is considered to have a higher level of trust than other nations in the region (Huff \& Kelley, 2003; Panatik, 2012). This is consistent with Gould-Williams and Mohamed's (2010) finding that human resource management practices in Malaysian organisations were relatively stronger than those of other countries. In the current study, using the Malaysian context, we investigate how management trust can significantly impact employees' performance and well-being, especially by providing job resources (i.e., personal development). Burnout and sleeping problems were also used as indicators of well-being as recommended in previous studies (Bourbonnais et al., 2006; Cheng \& Cheng, 2016; Elovainio, Kivimäki, Vahtera, Keltikangas-Järvinen, \& Virtanen, 2003).

\section{LITERATURE REVIEW}

\section{Management Trust, Job Performance, and Sleeping Problems}

Thus far, research has revealed how management's trust with respect to employees leads to positive employee outcomes, especially regarding job performance. This is because employers' trust entails a sense of employee empowerment (Cho \& Poister, 2013). Managements placing high trust on employees are less likely to be overly controlling of employee behaviour (Kramer, 1999). Their employees have more influence in decision making, engage in more open communication with employers, and possess the ability to develop self-confidence as members of the organisation (Ben-Ner \& Putterman, 2009; Parks \& Hulbert, 1995).

Empowered with the trust of higher management, employees feel a sense of responsibility to perform well on the work they are entrusted with. Consequently, this 
positively influences employees' happiness and motivates them to perform better at work (Antoni \& Hertel, 2009). This finding is consistent with social exchange theory (SET) (Cropanzano \& Mitchell, 2005), which describes human relationships as being reciprocal in nature. This means that when management treats employees well, the organisation will also benefit from greater efforts at task completion by their employees. To explain this reciprocal relationship, Carter and Mossholder (2015) clarified how trust congruence between managers and employees may develop intimate relationships that will lead to better job performance. Although the direction from which trust originates within the organisation is yet to be definitively concluded, for example whether trust among managers emerges from consistently positive work outcomes or whether managers' trust motivates better employee efforts (Carter \& Mossholder, 2015), Zapata, Olsen, and Martins (2013) asserted that when subordinates trust their supervisors, this trust is reciprocated. In addition, as trust may also facilitate goal accomplishment norms over time (Drescher, Korsgaard, Welpe, Picot, \& Wigand, 2014), these relationships will perhaps lead to more positive work outcomes.

H1: Management trust climate positively relates to job performance.

Good management practice through organisational support has been found to reduce negative psychological and health problems such as anger and depression among employees (Richardson, Yang, Vandenberg, DeJoy, \& Wilson, 2008). Some job stress theories, such as the job demands-control (Karasek, 1979) and the JD-R model (Bakker \& Demerouti, 2007), highlighted how working with low supervisory support can be detrimental to one's psychological health. Conversely, we expect a high trust level between employers and employees through open communication and honesty (Folger \& Cropanzano, 1998) to create a positive working environment that will reduce health problems.

We expect management trust to enhance employees' well-being in ways such as decreasing sleeping problems. Health problems such as burnout and sleeping problems have been widely investigated in literature (e.g., Elovainio et al., 2014; Kilroy, Flood, Bosak, \& Chênevert, 2016). Studies have begun to report the impact of sleep quality on employees' performance and productivity (Hui \& Grandner, 2015). Sleep problems may hinder or reduce productivity, leading to poor decision making and even absenteeism (Danna \& Griffin, 1999). To date, studies have discovered that a conducive and supportive working environment, particularly one fostering a good relationship between employers and employees, will improve employees' sleep quality (Wilson, DeJoy, Vandenberg, Richardson, \& McGrath, 2004).

$\mathrm{H} 2$ : Management trust climate negatively relates to sleeping problems. 


\section{Management Trust and Job Resources}

As previously noted, the linkage between management trust and employees' job performance has been observed by several studies (Colquitt et al., 2007; Dirks $\&$ Ferrin, 2002). Dirks and Ferrin's study (2002) revealed that trust impacts employees' job performance by promoting increased reciprocal care and concern in relationships and higher confidence among employees regarding their manager's character. However, it is still unknown how management trust boosts job performance through the enhancement of job resources. Previous studies have found that several organisational contexts such as organisational leadership (Tuckey, Bakker, \& Dollard, 2012) and organisational climate (Dollard \& Bakker, 2010) may function as antecedents to job resources. Using a similar argument, we posit that managers who choose to place sufficient trust in employees will provide a better working environment for them. This also translates into the protection of employees from possible psychosocial harm and indirectly enhances their job performance. In the context of the current study, we expect managers concerned about trust relationships to provide better job resources, thereby enabling employees to achieve their work goals. Job resources, according to Bakker and Demerouti (2007, p. 312), are defined as:

Any physical, psychological, social or organisational aspects of the job that are functional and beneficial in achieving work goals, reduce job demand, or any which that is associated with the physiological or psychological cost to it, in addition to stimulating individual growth, learning and development.

Since job resources vary, we used personal development as an indicator of job resources in the current study. We proposed personal development as an outcome since management trust climate is considered to be "a valued resource of any organisation and is a necessary component of a positive, healthy work environment" (Lambert, Hogan, Barton-Bellessa, \& Jiang, 2012, p. 938). This is consistent with the argument that a higher trust climate prioritises growth and learning among employees (Costigan, Liter, \& Berman, 1998). In other words, it represents greater management trust in employees' ability to utilise their skills (Tansky \& Cohen, 2001). A study by Kiffin-Petersen and Cordery (2003) of 218 employees in 40 teams, for example, discovered that working in a high-trust environment led employees to higher levels of teamwork since they became more aware of opportunities for their skills to be utilised. This finding is also consistent with the suggestion that when there is a higher level of trust, more resources are available and exchanged, thus benefitting employees (Jain, Sandhu, \& Goh, 2015; Poon, 2006). 
How management trust enhances personal development can be explained using a model of group development in which the way supervisors and subordinates trust each other may lead to proper processes and structures for task completion (see Kozlowski, Gully, Nason, \& Smith, 1999). This involves task-related group development that emphasises knowledge sharing and skill reinforcement as part of workgroup processes. This development will occur repeatedly, especially when the group needs to solve complex problems (Kozlowski et al., 1999). These conjectures lead to the following hypotheses:

H3: Management trust climate positively relates to personal development.

H4: Personal development mediates the relation between management trust climate and job performance.

A plethora of studies have discovered that job resources act as triggers for better job performance, especially through incremental job engagement (Rich, Lepine, \& Crawford, 2010). In addition, job resources have also been found to reduce job burnout, especially in situations wherein employees suffer from high job demands (Bakker, Demerouti, \& Euwema, 2005). Burnout not only reduces job performance but also leads to lower job satisfaction, more illnesses and greater turnover intentions (Demerouti, Bakker, \& Leiter, 2014; Wang, Hall, \& Rahimi, 2015). The establishment of engagement and burnout as opposite constructs within the JD-R model is supported in both Eastern and Western contexts (e.g., Idris, Dollard, \& Winefield, 2011; Roslan, Ho, Ng, \& Sambasivan, 2015; Trépanier, Fernet, Austin, Forest, \& Vallerand, 2014). Since engagement and burnout are two antipodes - employees suffering from burnout are unlikely to have higher job engagement (Schaufeli, Salanova, Gonzalez-Roma, \& Bakker, 2002) - we expect employees who perceive themselves to have higher job resources (i.e., personal development) to experience higher levels of job engagement and less burnout.

According to the conservation of resources theory (Hobfoll, 2001), an individual will protect his/her resources as resources are able to protect the individual from harmful situations. If the individual perceives sufficient resources are available to cope with strain, these resources will serve as buffers and shield that individual from the negative impacts of unnecessary threats (i.e., job demands). Studies have found a combination of high levels of job resources and low job demands predicted lower levels of burnout (Schaufeli, Bakker, \& Van Rhenen, 2009) and triggered higher job engagement (Tuckey et al., 2012). Schaufeli and Bakker (2004) argued that burnout exists because of not only the presence of high job demands but also a lack of job resources. Hence, given that personal development is a type of job 
resource, it also has the ability to reduce burnout among employees by building up resources over time. We thus propose the following hypotheses:

H5: Personal development positively relates to engagement.

H6: Personal development negatively relates to burnout.

Several studies have shown that engagement affects job performance. Owens, Baker, Sumpter, and Cameron (2015), and Schaufeli et al. (2002) found that employees who are engaged are psychologically energised and emotionally positive. Hence, they are able to work effectively. Moreover, engagement has been characterised as a positive spiral agent and serves as a mediator between job resources and job performance (Hakanen, Perhoniemi, \& Toppinen-Tanner, 2008; Salanova, Agut, \& Peiro, 2005).

Recent studies have assumed burnout to be an effective indicator of employees' well-being (Halbesleben, 2010). While engagement is linked to positive outcomes, scholars argue that burnout may negatively impact work, for example, by leading to health problems (Ekstedt et al., 2003; Maslach, Schaufeli, \& Leiter, 2001). Several researchers have discovered that burnout increases sleeping problems. For example, Cheng and Cheng (2016) studied 16,440 samples and found that high burnout was linked to sleeping problems (i.e., short sleeping duration and insomnia). Similarly, Bourbonnais et al. (2006) studied 613 samples over one year period found that burnout and sleeping problems were closely related. These health problems were due to a lack of job resources and high job demands. This scenario can be explained using the health erosion pathway (Bakker \& Demerouti, 2007) on how negative demands at work physically overtax employees, depleting their energy resources and causing negative responses. Accordingly, we advance the following hypotheses:

H7: Engagement positively relates to job performance.

H8: Burnout positively relates to sleeping problems.

H9: Engagement mediates personal development and job performance.

\section{Research Framework}

This study intends to test the nine hypotheses presented, and our research model is shown in Figure 1. 


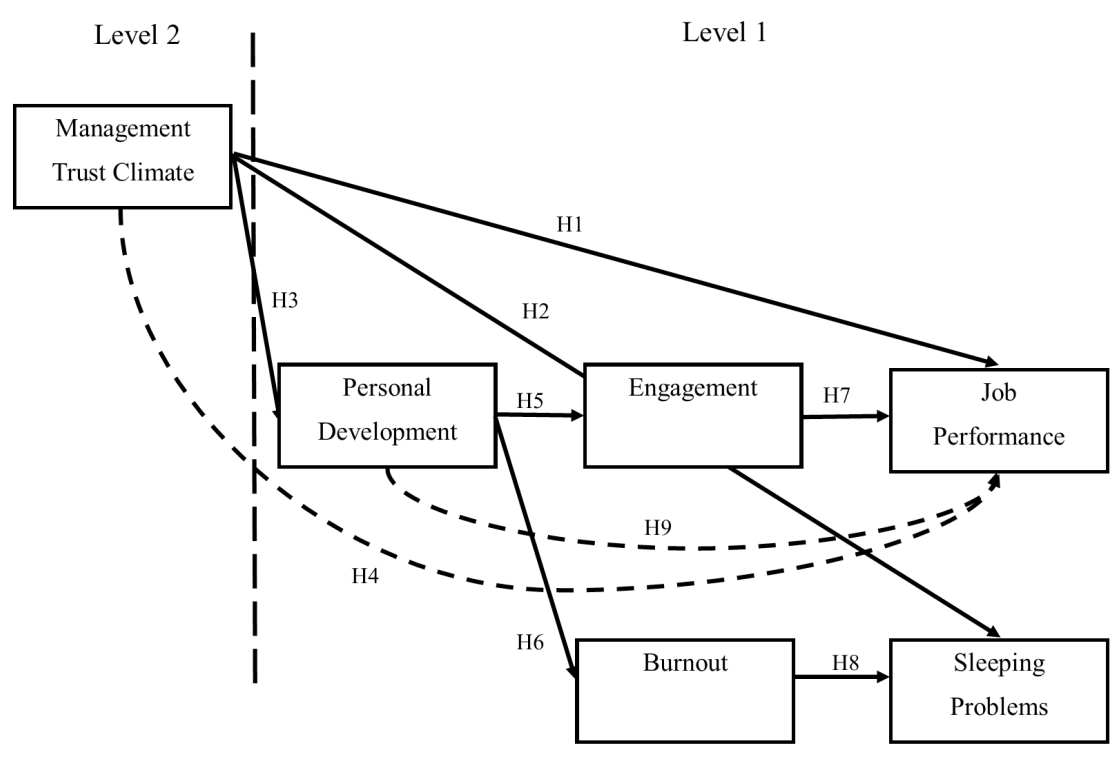

Figure 1. Research model

\section{METHODOLOGY}

\section{Participants}

The current study employed a cross-sectional multilevel design and a snowball sampling method. Participants were 377 employees $^{1}$ [average age $=37.42$ years old; standard deviation (SD) $=18.53$ ] from 44 private organisations in Malaysia. Only those who were working as white-collar employees with full-time jobs at that particular organisation were included in the study. The majority of participants were women $(\mathrm{N}=204,54.1 \%)$, and most were Malaysians $(\mathrm{N}=364,96.6 \%)$. Most participants were married $(\mathrm{N}=270,71.6 \%)$, followed by those who were unmarried and single $(\mathrm{N}=103,27.3 \%)$, and a small minority were divorced $(\mathrm{N}=4,1.1 \%)$. The participants worked in several sectors, including the service industry (63.9\%) and consumer product industry $(18.3 \%)$, with the remainder working in other industries. The number of participants per team ranged from four to nine. 


\section{Instruments}

Management trust climate was measured using four items from the 'Trust Regarding Management' subscales of the short version of the Copenhagen Psychosocial Questionnaire II (COPSOQ II) (Pejtersen, Kristensen, Borg, \& Bjorner, 2010). The scale ranges from 1 (to a very small extent) to 5 (to a very large extent) and comprises items such as "Does the management trust you to do your work well?" Cronbach's alpha for this scale is .73.

Personal development was measured using four items of the 'Possibility for Development' scale of the COPSOQ (Kristensen \& Borg, 2003). The scale ranges from 1 (to a very small extent) to 5 (to a very large extent) and comprises items such as "Can you use your skills or expertise in your work?" The reported alpha reliability is .88 .

Engagement was measured using nine items of the short version of the Utrecht Work Engagement Scale (UWES-9) (Schaufeli, Bakker, \& Salanova, 2006) which comprises three subscales: (1) vigour (e.g., "At work I feel strong and energetic"), $\alpha=.84$; (2) dedication (e.g., "I am proud of the work I do"), $\alpha=.88$; and (3) absorption (e.g., "I get carried away while at work"), $\alpha=.84$. Factor analysis showed high correlations for all nine items, and principle component analysis showed engagement as a one-factor component, with alpha reliability of .93 .

Burnout was measured using 16 items from the Oldenburg Burnout Inventory (OLBI) (Demerouti, Bakker, Vardakou, \& Kantas, 2003). The scale is divided into two subscales - exhaustion and disengagement - with seven items each. These items are coded with a Likert-scale ranging from 1 (strongly disagree) to 4 (strongly agree). Four items from each subscale are reversed coded so that higher scores indicate greater burnout (Demerouti, Mostert, \& Bakker, 2010). The scale comprises items such as "After my work, I usually feel worn out and weary." Previous studies have found the OLBI to have acceptable internal consistency and convergent validity with other scales commonly used to measure burnout (Demerouti et al., 2003; 2010). The reported alpha reliability is .80 .

Job performance was measured using three items from the World Health Organization Health and Work Performance Questionnaire (HPQ) (Kessler et al., 2003) which ranges from 1 (worst job performance anyone could have) to 10 (performance of a top worker). The participants were asked to rate themselves in terms of their usual performance and also rank their performance over the past 28 days using a 10-point scale. The scale contains items such as "How would you rate 
the usual performance of most workers in a job similar to yours?" The reported alpha reliability for the scale is .76 .

Sleeping problems was measured using the 'Sleeping Troubles' dimension of the Health and Well-Being domain in the COPSOQ II (Kristensen, Hannerz, Høgh, \& Borg, 2005). It was measured using a five-point Likert-scale ranging from 1 (not at all) to 5 (all the time) which includes items such as "How often have you slept badly and restlessly?" The reported alpha reliability is .91 .

\section{Data Collection Procedure}

The researchers of the current study first sent out e-mails to private organisations within the Klang Valley region and then set up appointments with the department heads to brief them on the study. Only one department was selected from each organisation. The participants then received an envelope containing the questionnaire, completed it and sealed it before returning it to the researchers. Upon completion of data collection from each organisation, the researchers then asked the participants if they knew of any other organisations that would be interested to participate in the study. They would then pass the researchers details of a contact person within the organisations and thereafter, the researchers would laisse with the individual. The criteria to snowballing were each organisation should have at least four participants in a department, the participants should be working full time, and would have worked with that particular organisation for at least six months in order to capture the organisational climate (Zapf, Dormann, \& Frese, 1996). This study was modelled on studies by Kidwell, Mossholder, and Bennett (1997), and Liao and Chuang (2004); a range of industries were included to reduce respond bias based on similar industries or organisational characteristics, in addition to allow more generalised findings.

\section{Statistical Analyses}

Prior to multilevel analyses, the trust climate of upper-level management was analysed to ascertain whether it showed group-level properties and could be aggregated. Index of agreement, r(WG)(J) (see James, Demaree, \& Wolf, 1984), was high, with a value of .96 (LeBreton \& Senter, 2008). We also tested Intraclass Correlation Coefficient ICC(I) to check organisational variance for management trust climate at Time 1 and it showed .19, indicating that $19 \%$ of the variance in management trust climate was due to organisational factors. A range from .05 to .20 is acceptable for aggregation (Bliese, 2000). $\mathrm{F}_{\text {III }}$ ) for management trust climate $=1.85, p<.01$, indicating further support for between-organisation differences for management trust climate. These tests were conducted using SPSS version 21.0. 
We then employed the Hierarchical Linear Modeling 6.08 (HLM) software to test all hypotheses.

Three types of analyses were used in this study to test the hypotheses: lower-level direct effects, cross-level direct effects, and mediation effects. Lower-level direct effects and cross-level direct effects were tested using Mathieu and Taylor's (2007) recommendations. First, we ran a cross-level direct effects analysis $(\mathrm{H} 1, \mathrm{H} 2$, and H3), which tested the effects of management trust climate on personal development, engagement and job performance, thereby controlling for the dependent variable. Below is an example of a cross-level HLM equation:

\section{Level 1 Model}

Job performance $=\beta_{0}+\beta_{1}($ Job performance $)+r$

Level 2 Model

$$
\begin{aligned}
& \beta_{0 \mathrm{j}}=\mathrm{G}_{00}+\mathrm{G}_{01} \text { (Management trust) }+\mathrm{u}_{0 \mathrm{j}} \\
& \beta_{1 \mathrm{j}}=\mathrm{G}_{10}+\mathrm{G}_{11} * \mathrm{~W}_{\mathrm{j}} \mathrm{j}+\mathrm{u}_{1 \mathrm{j}}
\end{aligned}
$$

For lower-level direct effects (H5, H6, H7, and H8), the lower variables' dependent variable was regressed on a predictor controlling for the dependent measure.

$$
\text { Engagement }=\beta_{0}+\beta_{1}(\text { Personal development })+\beta(\text { Engagement })+r
$$

Finally, to test mediation effects (H4 and H9), each part of the mediation pathway $a b$ was tested using estimates of path $a(\mathrm{X} \rightarrow \mathrm{M})$ and path $b(\mathrm{M} \rightarrow \mathrm{Y})$ For example, to test H4, the following criteria must be fulfilled (Baron \& Kenny, 1986). First, a significant relation must hold between $X \rightarrow Y$ (management trust climate $\rightarrow$ job performance) (Model 6). Second, significant relation must hold between $\mathrm{X} \rightarrow \mathrm{M}$ (management trust climate $\rightarrow$ personal development) (Model 9). Third, a significant relation must hold between $\mathrm{M} \rightarrow \mathrm{Y}$, controlling $\mathrm{Y}, \mathrm{M}$, and $\mathrm{X}$ (personal development $\rightarrow$ job performance, controlling job performance, personal development, and management trust climate) (Model 7). If the third criterion is not met, then partial mediation holds. The Monte Carlo test (Selig \& Preacher, 2008) was chosen over the Sobel test since it is considered to be more applicable to cases of mediation in multilevel analyses (MacKinnon, Lockwood, \& Williams, 2004). The Monte Carlo test had a 95\% confidence interval and 20,000 repetitions. 


\section{RESULTS}

Table 1 presents the demographic details of the participants. Results for HLM analysis are shown in Tables 2 and 3. A summary of the findings is presented in Figure 2.

Table 1

Demographic details of participants $(N=377)$

\begin{tabular}{|c|c|c|c|}
\hline Variable & $\mathrm{N}(\%)$ & M & $\mathrm{SD}$ \\
\hline \multicolumn{4}{|l|}{ Gender } \\
\hline Male & $173(45.9)$ & & \\
\hline Female & $204(54.1)$ & & \\
\hline Age & & 37.42 & 18.53 \\
\hline \multicolumn{4}{|l|}{ Nationality } \\
\hline Malaysian & $364(96.6)$ & & \\
\hline Non-Malaysian & $12(3.2)$ & & \\
\hline \multicolumn{4}{|l|}{ Marital status } \\
\hline Single & $103(27.3)$ & & \\
\hline Married & $270(71.6)$ & & \\
\hline Divorced & $4(1.1)$ & & \\
\hline \multicolumn{4}{|l|}{ Ethnicity } \\
\hline Malays & $243(64.5)$ & & \\
\hline Chinese & $54(14.3)$ & & \\
\hline Indian & $54(14.3)$ & & \\
\hline Others & $26(6.9)$ & & \\
\hline \multicolumn{4}{|l|}{ Industry } \\
\hline Service & $241(63.9)$ & & \\
\hline Consumer products & $69(18.3)$ & & \\
\hline Finance & $22(5.8)$ & & \\
\hline Others & 45 (11.9) & & \\
\hline Working hours/week & & 44.2 & 11.22 \\
\hline
\end{tabular}

Note: $\mathrm{N}=$ number; $\mathrm{M}=$ mean; $\mathrm{SD}$ = standard deviation 
Table 2

HLM analyses of lower-level outcomes

\begin{tabular}{lccccc}
\hline Effect & $\begin{array}{c}\text { Job } \\
\text { performance }\end{array}$ & $\begin{array}{c}\text { Job } \\
\text { performance }\end{array}$ & $\begin{array}{c}\text { Sleeping } \\
\text { troubles }\end{array}$ & Engagement & Burnout \\
\hline Model & 1 & 2 & 3 & 4 & 5 \\
Lower-level effects & & & & & \\
Engagement & $.51(.06)^{*}$ & $.43(.06)^{*}$ & & & \\
$\begin{array}{l}\text { Burnout } \\
\begin{array}{l}\text { Personal } \\
\text { development }\end{array}\end{array}$ & & $.42(.06)^{*}$ & & \\
\hline
\end{tabular}

Notes: The first value is the unstandardised parameter estimate, and the value in parenthesis is the standard error. $\mathrm{N}=377,44$ organisations; $* p<.001$

Table 3

HLM analyses of cross-level effects of management trust climate on lower-level outcomes

\begin{tabular}{ccccc}
\hline Effect & $\begin{array}{c}\text { Job } \\
\text { performance }\end{array}$ & $\begin{array}{c}\text { Job } \\
\text { performance }\end{array}$ & $\begin{array}{c}\text { Sleeping } \\
\text { troubles }\end{array}$ & $\begin{array}{c}\text { Personal } \\
\text { development }\end{array}$ \\
\hline Model & 6 & 7 & 8 & 9
\end{tabular}

Lower-level effects

Engagement

Burnout

Personal development

$.40(.07)^{*}$

Cross-level effects

$\begin{array}{lllll}\text { Climate of management } & .34(.07)^{*} & .35(.06)^{*} & -.07(.09) & .46(.09)^{*}\end{array}$ trust

H1 predicted that management trust climate positively relates to job performance. A significant effect was found, as indicated in Model 6. H1 was supported $(\gamma=.34, p<.001) . \mathrm{H} 2$ predicted that management trust climate negatively relates to sleeping problems. No significant effect was found, as indicated in Model 8. Thus, $\mathrm{H} 2$ was not supported $(\gamma=-.07, p>.05)$. H3 predicted that management trust climate positively relates to personal development. A significant effect was found, as indicated in Model 9, thus supporting H3 $(\gamma=.46, p<.001)$. H4 predicted that personal development mediates management trust climate and job performance. In testing the hypothesis, the conditions assumed by Baron and Kenny (1986) were fulfilled. The only exception was that the main effect of management trust climate on job performance was still significant when personal development was added to the model, indicating that the effect was only partially mediated. The mediation effect was tested using the parameter estimate from Model 9 as the value 
of the direct effect between management trust climate and personal development $(\gamma=.46, \mathrm{SE}=.09)$, and the parameter estimate from Model 7 was used to estimate the relation of personal development and job performance with management trust climate in the model $(\beta=.40, \mathrm{SE}=.07)$. We tested the significance of the indirect parameter estimate using a Monte Carlo test to determine the significance of the indirect parameter estimate. Management trust climate was found to have a significant lagged effect on job performance through personal development [95\% confident interval (CI), lower level $(\mathrm{LL})=.0976$, upper level $(\mathrm{UL})=.2886$ ] Since the effect of management trust climate on job performance was significant in the presence of the mediator (personal development) in the model, this indicates that the effect was partially mediated.

H5 predicted that personal development positively relates to engagement. A significant effect was found (see Model 4), supporting H5 ( $\beta=.33, p<.001)$. H6 predicted that personal development negatively relates to burnout. A significant effect was found (see Model 5), supporting H8 $(\beta=.-30, p<.001)$. H7 predicted that engagement positively relates to job performance. A significant effect was found, as indicated in Model 1 , supporting H6 ( $\beta=.51, p<.001)$.

H8 predicted that burnout positively relates to sleeping problems. A significant effect was found, as indicated in Model 3, supporting H8 $(\beta=.42, p<.001)$. $\mathrm{H} 9$ predicted that engagement mediates personal development and job performance. In testing the hypothesis, the conditions outlined by Baron and Kenny (1986) were fulfilled. The mediation effect was tested using the parameter estimate from Model 4 as the value for the direct effect between personal development and engagement $(\gamma=.25, \mathrm{SE}=.07)$, and the parameter estimate from Model 2 estimated the relation between engagement and job performance with personal development $(\beta=.43, \mathrm{SE}=.06)$. We evaluated the significance of the indirect parameter estimate using a Monte Carlo test to determine the significance of the indirect parameter estimate. The results revealed that personal development had a significant lagged effect on job performance through engagement $(95 \% \mathrm{CI}$, $\mathrm{LL}=.07625, \mathrm{UL}=.2188$ ). Since the effect of personal development on job performance was significant in the presence of engagement, the mediator in the model, the effect was thus partially mediated. 


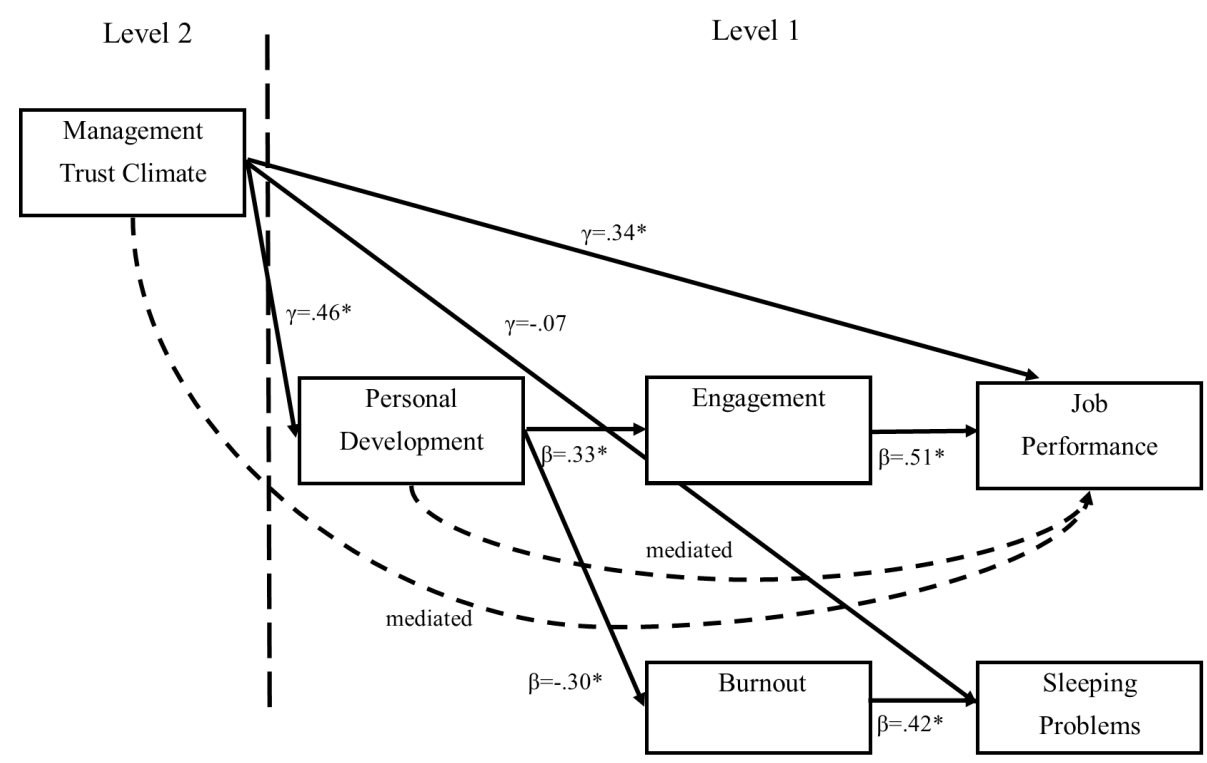

Figure 2. The final model

\section{DISCUSSION}

The current study's main objective was to investigate the cross-level effects of management trust climate on employees' job performance and sleeping problems, particularly through personal development, engagement, and burnout. We tested our research model by conducting cross-sectional multilevel analyses on 377 employees in 44 private organisations in Malaysia.

Overall, we found that personal development, a type of job resource, led to better work outcomes and well-being. This is consistent with past literature that has demonstrated job resources to be a positive spiral agent for positive work outcomes and a buffer against negative elements. We found that management trust climate improved job performance, particularly through personal development and job engagement. Thus, trust through a proximal referent leads to increased focus on work-related tasks (Frazier, Johnson, Gavin, Gooty, \& Snow, 2010). This finding is consistent with similar previous studies that have indicated how management trust exhibits job performance among employees (Mayer \& Gavin, 2005; Rich, 1997). 
Our results also suggest that personal development mediated the relation between management trust climate and engagement, and engagement mediated the relation between personal development and job performance. Although previous studies have identified the mechanisms by which management trust cultivates a norm for task completion (Dirks \& Ferrin, 2002; McCauley \& Kuhnert, 1992), we offer a more insightful explanation. We found that management trust may also cultivate positive working conditions, specifically by enhancing employees' personal development. As an indirect effect, employees become more engaged with their jobs and therefore more productive. This finding shows how job resources lead to higher levels of engagement and thus higher levels of energy and passion for one's work (Lee, Idris, \& Delfabbro, 2016). So far, research in this area, especially by scholars who only use the JD-R model to explain the relation between job characteristics and engagement, has only been conducted at the individual level (Schaufeli \& Bakker, 2004). The current study, however, considers organisational context as an antecedent to job characteristics and engagement. We discovered that management trust not only contributes to better job performance but also is a precursor to employees' working conditions. Hence, this supports the idea that employees' behaviour can be affected by their working environment (Lee \& Idris, 2017). This is particularly important considering the fact that Malaysia is a collectivistic country where the environment exerts considerable influences on individuals (Poon, 2006).

In addition, we also discovered how management trust impacts employees' health. While several studies have attempted to explain how health problems may result from poor working conditions (Hakanen, Bakker, \& Schaufeli, 2006; Karasek \& Theorell, 1992), little evidence exists on the important role upper-level contexts may play on employees' well-being. So far, scholars have argued that some leadership styles (i.e., transformational leadership; Nielsen, Yarker, Randall, \& Munir, 2009) or specific organisational climates (i.e., psychosocial safety climate; Dollard \& Bakker, 2010) may affect employees' health through working conditions. However, we found that a management trust climate may also decrease job burnout, particularly through the enhancement of personal development. Although we were unable to find any evidence supporting the relation between management climate and sleeping problems, the insignificance of this relation may be due to a distal effect (Zapf et al., 1996) as some effects may take longer to develop.

\section{Practical Implications}

Trust in the working environment serves as a signal of management's belief in employees' ability to produce desirable work outcomes for their organisation (Pierce, O'Driscoll, \& Coghlan, 2004). It shows how a positive working 
environment can improve employees' motivation (Lee et al., 2016). Dulebohn, Bommer, Liden, Brouer, and Ferris (2012) commented on the low levels of trust in collectivist countries that also have high power distance. A conducive working environment such as one with a strong climate of management trust will facilitate a healthy working environment. With the close-knit relationships common in the Malaysian context, organisations may use management trust as leverage in cultivating positive relationships with employees (Huff \& Kelley, 2003; Jogulu \& Ferkins, 2012).

Upper management may want to implement approaches for demonstrating trust in their employees. First, upper management could practise less stringent dayto-day monitoring of employees. They could also conduct an annual evaluation exercise for performance evaluation. Such an approach will appear more objective and comprehensive (Shafie, 1996). Second, upper management may delegate more decision making and control to employees, who will thus be empowered to make certain decisions without the approval or interference of upper management. That becomes a type of job resource for employees. Third, in the event that neither of these approaches is feasible, upper management can form groups or teams to complete projects or tasks. This would allow for more sharing of responsibilities and less strain and demand on any given employee (Sprigg, Jackson, \& Parker, 2000). Team members would also have more responsibility for the tasks they need to complete. They would also obtain more support from one another (De Jong \& Dirks, 2012). Not only would job performance be increased but also employees' creativity would also be enhanced (Zhang \& Zhou, 2014).

Personal development has been shown to be an antecedent for motivation and engagement among employees (Baldwin, Garza-Reyes, Kumar, \& Rocha-Lona, 2014; Teare, Cummings, Donaldson-Brown, \& Spittle, 2011). One of the ways employees seek meaning in their work is through their ability to contribute to the organisation. Organisations should therefore acknowledge every employee's skills and abilities. To maximise employees' potential, organisations can rely on employee's knowledge, skills, abilities, and other characteristics (KSAOs) in completing tasks and jobs. In addition, organisations may conduct courses to promote employees' development through training and mentorship (Broadhurst, 2012). With Malaysia being the 18th-most competitive country in the world (World Economic Forum, 2015), having sufficient KSAOs will be beneficial for employees' productivity. 


\section{CONCLUSION}

The present study has shown that personal development can increase employees' engagement and job performance. Management trust climate has also been shown to promote personal development in employees. Personal development mediated management trust climate and engagement. It also resulted in lower levels of burnout in cases wherein burnout led to higher sleeping problems. Overall, this study presents a model wherein management trust climate is able to provide job resources and better employees' well-being.

\section{NOTES}

1. According to Hox (2002) and Maas and Hox (2005), the effective sample size for this group (average level-2 group size at $8.57, \mathrm{~N}=44$ ) of participants is 155 . Hence, 377 offered a sufficient sample size and power (in reducing type II error) for analyses.

\section{REFERENCES}

Akkermans, J., Schaufeli, W.B., Brenninkmeijer, V., \& Blonk, R.W.B. (2013). The role of career competencies in job demands: Resource model. Journal of Vocational Behaviour, 83(3), 356-366. https://doi.org/10.1016/j.jvb.2013.06.011

Antoni, C., \& Hertel, G. (2009). Team processes, their antecedents and consequences: Implications for different types of teamwork. European Journal of Work and Organizational Psychology, 18(3), 253-266. https://doi. org/10.1080/13594320802095502

Aryee, S., Budhwar, P.S., \& Chen, Z.X. (2002). Trust as a mediator of the relationship between organizational justice and work outcomes: Test of a social exchange model. Journal of Organizational Behavior, 23(3), 267-285. https://doi. org/10.1002/job.138

Bakker, A.B., \& Demerouti, E. (2007). The job demands-resources model: State of the art. Journal of Managerial Psychology, 22(3), 309-328. https://doi. org/10.1108/02683940710733115

Bakker, A.B., Demerouti, E., \& Euwema, M.C. (2005). Job resources buffer the impact of job demands on burnout. Journal of Occupational Health Psychology, 10(2), 170-180. https://doi.org/10.1037/1076-8998.10.2.170

Baldwin, C., Garza-Reyes, J.A., Kumar, V., \& Rocha-Lona, L. (2014). Personal Development Review (PDR) process and engineering staff motivation: A case study investigation in a manufacturing firm. Journal of Manufacturing Technology Management, 25(6), 827-847. https://doi.org/10.1108/JMTM-01-2013-0001 
Baron, R.M., \& Kenny, D.A. (1986). The moderator-mediator variable distinction in social psychological research: Conceptual, strategic, and statistical considerations. Journal of Personality and Social Psychology, 51(6), 1173-1182. https://doi. org/10.1037/0022-3514.51.6.1173

Ben-Ner, A., \& Putterman, L. (2009). Trust, communication and contracts: An experiment. Journal of Economic Behavior \& Organization, 70(1-2), 106-121. https://doi. org/10.1016/j.jebo.2009.01.011

Bliese, P.D. (2000). Within-group agreement, non-independence, and reliability: Implications for data aggregation and analyses. In K.J. Klein \& S.W.J. Kozlowski (Eds.), Multilevel theory, research, and methods in organizations: Foundations, extensions, and new directions (pp. 349-381). San Francisco, CA: Jossey-Bass.

Bourbonnais, R., Brisson, C., Vinet, A., Vezina, M., Abdous, B., \& Gaudet, M. (2006). Effectiveness of a participative intervention on psychosocial work factors to prevent mental health problems in a hospital setting. Occupational and Environmental Medicine, 63(5), 335-342. https://doi.org/10.1136/oem.2004.018069 and https:// doi.org/10.1136/oem.2004.018077

Broadhurst, K. (2012). Moral agency in everyday safeguarding work: Reclaiming hope in the small stories of family support-some lessons from John Dewey. Families, Relationships and Societies, 1(3), 293-309. https://doi. org/10.1332/204674312X656248

Carter, M.Z., \& Mossholder, K.W. (2015). Are we on the same page? The performance effects of congruence between supervisor and group trust. Journal of Applied Psychology, 100(5), 1349-1363. https://doi.org/10.1037/a0038798

Cheng, W.J., \& Cheng, Y. (2016). Night shift and rotating shift in association with sleep problems, burnout and minor mental disorder in male and female employees. Occupational and Environmental Medicine, 74, 483-488. https://doi.org/10.1136/ oemed-2016-103898

Cho, Y.J., \& Poister, T.H. (2013). Human resource management practices and trust in public organizations. Public Management Review, 15(6), 816-838. https://doi.org /10.1080/14719037.2012.698854

Colquitt, J.A., Scott, B.A., \& LePine, J.A. (2007). Trust, trustworthiness, and trust propensity: A meta-analytic test of their unique relationships with risk taking and job performance. Journal of Applied Psychology, 92(4), 909-927. https://doi. org/10.1037/0021-9010.92.4.909

Costigan, R.D., Liter, S.E., \& Berman, J.J. (1998). A multi-dimensional study of trust in organizations. Journal of Managerial Issues, 10(3), 303-17.

Cropanzano, R., \& Mitchell, M.S. (2005). Social exchange theory: An interdisciplinary review. Journal of Management, 31(6), 874-900. https://doi. org/10.1177/0149206305279602

Daley, D.M., \& Pope, S.E. (2004). Perceptions of supervisory, middle managerial, and top managerial trust: The role of job satisfaction in organizational leadership. State \& Local Government Review, 36(2), 130-139. https://doi. org/10.1177/0160323X0403600204 
Danna, K., \& Griffin, R.W. (1999). Health and well-being in the workplace: A review and synthesis of the literature. Journal of Management, 25(3), 257-284. https://doi. org/10.1177/014920639902500305

De Jong, B.A., \& Dirks, K.T. (2012). Beyond shared perceptions of trust and monitoring in teams: Implications of asymmetry and dissensus. Journal of Applied Psychology, 97(2), 391-406. https://doi.org/10.1037/a0026483

Demerouti, E., Bakker, A.B., \& Leiter, M.H. (2014). Burnout and job performance: The moderating role of selection, optimization, and compensation strategies. Journal of Occupational Health Psychology, 19(1), 96-107. https://doi.org/10.1037/ a0035062

Demerouti, E., Bakker, A.B., Vardakou, I. \& Kantas, A. (2003). The convergent validity of two burnout instruments: A multitrait-multimethod analysis. European Journal of Psychological Assessment, 19(1), 12-23. https://doi.org/10.1027//10155759.19.1.12

Demerouti, E., Mostert, K., \& Bakker, A.B. (2010). Burnout and work engagement: A thorough investigation of the independency of both constructs. Journal of Occupational Health Psychology, 15(3), 209-222. https://doi.org/10.1037/ a0019408

Dirks, K.T., \& Ferrin, D.L. (2002). Trust in leadership: Meta-analytic findings and implications for research and practise. Journal of Applied Psychology, 87(4), 611-628. https://doi.org/10.1037/0021-9010.87.4.611

Dollard, M.F., \& Bakker, A.B. (2010). Psychosocial safety climate as a precursor to conducive work environments, psychological health problems, and employee engagement. Journal of Occupational and Organizational Psychology, 83(3), 579-599. https://doi.org/10.1348/096317909X470690

Drescher, M.A., Korsgaard, M.A., Welpe, I.M., Picot, A., \& Wigand, R.T. (2014). The dynamics of shared leadership: Building trust and enhancing performance. Journal of Applied Psychology, 99(5), 771-783. https://doi.org/10.1037/a0036474

Dulebohn, J.H., Bommer, W.H., Liden, R.C., Brouer, R., \& Ferris, G.R. (2012). A metaanalysis of the antecedents and consequences of leader-member exchange: Integrating the past with an eye towards the future. Journal of Management, 38(6), 1715-1759. https://doi.org/10.1177/0149206311415280

Ekstedt, M., Soderstrom, M., Nilsson, J., Kecklund, G., Perski, A., \& Akerstedt, T. (2003). Burnout syndrome is associated with markedly reduced sleep efficiency and SWS. Journal of Psychosomatic Research, 55(2), 135. https://doi.org/10.1016/ S0022-3999(03)00320-9

Elovainio, M., Heponiemi, T., Kuusio, H., Jokela, M., Aalto, A.M., Pekkarinen, L., \& Sinervo, T. (2014). Job demands and job strain as risk factors for employee wellbeing in elderly care: An instrumental-variables analysis. The European Journal of Public Health, 25(1), 103-108. https://doi.org/10.1093/eurpub/cku115

Elovainio, M., Kivimäki, M, Vahtera, J., Keltikangas-Järvinen, L., \& Virtanen, M. (2003). Sleeping problems and health behaviours as mediators between organizational justice and health. Health Psychology, 22(3), 287-293. https://doi. org/10.1037/0278-6133.22.3.287 
Ferres, N., Connell, J., \& Travaglione, A. (2004). Co-worker trust as a social catalyst for constructive employee attitudes. Journal of Managerial Psychology, 19(6), 608622. https://doi.org/10.1108/02683940410551516

Folger, R., \& Cropanzano, R. (1998). Organizational justice and human resource management. Beverly Hills, CA: Sage.

Frazier, M.L., Johnson. P., Gavin, M.B., Gooty, J., \& Snow, D.B. (2010). Organizational justice, trust and trustworthiness: Amultifoci examination. Group and Organization Management, 35(1), 39-76. https://doi.org/10.1177/1059601109354801

Gould-Williams, J., \& Mohamed, R.B. (2010). A comparative study of the effects of 'best practice' HRM on worker outcomes in Malaysia and England local government. The International Journal of Human Resource Management, 21(5), 653-675. https://doi.org/10.1080/09585191003658821

Hakanen, J.J., Bakker, A.B., \& Schaufeli, W.B. (2006). Burnout and work engagement among teachers. Journal of School Psychology, 43(6), 495-513. https://doi. org/10.1016/j.jsp.2005.11.001

Hakanen, J.J., Perhoniemi, R., \& Toppinen-Tanner, S. (2008). Positive gain spirals at work: From job resources to work engagement, personal initiative and workunit innovativeness. Journal of Vocational Behavior, 73(1), 78-91. https://doi. org/10.1016/j.jvb.2008.01.003

Halbesleben, J.R.B. (2010). Addressing stress and beating burnout: Engaging staff in stress reduction leads to more productive culture, greater patient satisfaction. Healthcare Executive, 25(2), 58-60.

Hobfoll, S.E. (2001). The influence of culture, community, and the nested-self in the stress process: Advancing conservation of resources theory. Applied Psychology: An International Review, 50(3), 337-370. https://doi.org/10.1111/1464-0597.00062

Hox, J. (2002). Multilevel analysis: Techniques and applications. Mahwah, NJ: Lawrence Erlbaum Associates.

Huff, L., \& Kelley, L. (2003). Levels of organizational trust in individualist versus collectivist societies: A seven-nation study. Organization Science, 14(1), 81-90. https://doi.org/10.1287/orsc.14.1.81.12807

Hui, S.K.A., \& Grandner, M.A. (2015). Associations between poor sleep quality and stages of change of multiple health behaviours among participants of employee wellness programs. Preventive Medicine Reports, 2, 292-299. https://doi.org/10.1016/j. pmedr.2015.04.002

Idris, M., Dollard, M., \& Winefield, K. (2011). Integrating psychosocial safety climate in the JD-R model: A study amongst Malaysian workers. SA Journal of Industrial Psychology, 37(2), 1-11. https://doi.org/10.4102/sajip.v37i2.851

Jain, K.K., Sandhu, M.S., \& Goh, S.K. (2015). Organizational climate, trust, and knowledge sharing: Insights from Malaysia. Journal of Asia Business Studies, 9(1), 54-77. https://doi.org/10.1108/JABS-07-2013-0040

James, L.R., Demaree, R.G., \& Wolf, G. (1984). Estimating within-group interrater reliability with and without response bias. Journal of Applied Psychology, 69(1), 85-98. https://doi.org/10.1037/0021-9010.69.1.85 
Jogulu, U., \& Ferkins, L. (2012). Leadership and culture in Asia: The case of Malaysia. Asia Pacific Business Review, 18(4), 531-549. https://doi.org/10.1080/13602381 .2012 .690301

Karasek Jr., R.A. (1979). Job demands, job decision latitude, and mental strain: Implications for job redesign. Administrative Science Quarterly, 24(2), 285-308. https://doi. org $/ 10.2307 / 2392498$

Karasek, R.A., \& Theorell, T. (1992) Healthy work: Stress, productivity, and the reconstruction of working life. New York: Basic Books.

Kessler, R.C., Barber, C., Beck, A.L., Berglund, P.A., Cleary, P.D., McKenas, D., \& Wang, P.S. (2003). The World Health Organization health and work performance questionnaire (HPQ). Journal of Occupational and Environmental Medicine, 45(2), 156-174. https://doi.org/10.1097/01.jom.0000052967.43131.51

Kidwell, R.E., Mossholder, K.W., \& Bennett, N. (1997). Cohesiveness and organizational citizenship behaviour: A multilevel analysis using work groups and individuals. Journal of Management, 23(6), 775-793. https://doi. org/10.1177/014920639702300605

Kiffin-Petersen, S., \& Cordery, J. (2003). Trust, individualism and job characteristics as predictors of employee preference for teamwork. International Journal of Human Resource Management, 14(1), 93-116. https://doi. org/10.1080/09585190210158538

Kilroy, S., Flood, P.C., Bosak, J., \& Chênevert, D. (2016). Perceptions of high-involvement work practices, person-organization fit, and burnout: A time-lagged study of health care employees. Human Resource Management, 56(5), 821-835. https:// doi.org/10.1002/hrm.21803

Kozlowski, S.W., Gully, S.M., Nason, E.R., \& Smith, E.M. (1999). Developing adaptive teams: A theory of compilation and performance across levels and time. In D.R. Ilgen \& E.D. Pulakos (Eds.), The changing nature of performance: Implications for staffing, motivation, and development (pp. 240-292). San Francisco: JosseyBass.

Kramer, R.M. (1999). Trust and distrust in organizations: Emerging perspectives, enduring questions. Annual Review of Psychology, 50(1), 569-598. https://doi.org/10.1146/ annurev.psych.50.1.569

Kristensen, T.S., \& Borg, V. (2003). Copenhagen Psychological Questionnaire (COPSOQ): A questionnaire on psychosocial working conditions, health and well-being in three versions. Unpublished manuscript, National Institute of Occupational Health, Denmark.

Kristensen, T.S., Hannerz, H., Høgh, A., \& Borg V. (2005). The Copenhagen Psychosocial Questionnaire: A tool for the assessment and improvement of the psychosocial work environment. Scandinavian Journal of Work and Environmental Health, 31(6), 438-449. https://doi.org/10.5271/sjweh.948

Lambert, E.G., Hogan, N.L., Barton-Bellessa, S.M., \& Jiang, S. (2012). Examining the relationship between supervisor and management trust and job burnout among correctional staff. Criminal Justice and Behavior, 39(7), 938-957. https://doi. org/10.1177/0093854812439192 
LeBreton, J.M. \& Senter, J.L. (2008). Answers to 20 questions about interrater reliability and interrater agreement. Organizational Research Methods, 11(4), 815-852. https://doi.org/10.1177/1094428106296642

Lee, M.C.C., \& Idris, M.A. (2017). Psychosocial safety climate versus team climate: The distinctiveness between the two organizational climate constructs. Personnel Review, 46(5), 988-1003. https://doi.org/10.1108/PR-01-2016-0003

Lee, M.C.C., Idris, M.A., \& Delfabbro, P. (2016). The linkages between hierarchical culture and empowering leadership and their effects on employees' job engagement: Work meaningfulness as a mediator. International Journal of Stress Management, 24(4), 392-415. https://doi.org/10.1037/str0000043

Li, L., Wang, Y., \& Lim, E.P. (2009) Trust-oriented composite service selection and discovery. In L. Baresi, C.H. Chi, \& J. Suzuki (Eds.), Service-oriented computing. Lecture notes in Computer Science (Vol 5900). Heidelberg, Berlin: Springer. https://doi.org/10.1007/978-3-642-10383-4_4

Li, N., \& Yan, J. (2009). The effects of trust climate on individual performance. Frontiers of Business Research in China, 3(1), 27-49. https://doi.org/10.1007/s11782-0090002-6

Liao, H., \& Chuang, A. (2004). A multilevel investigation of factors influencing employee service performance and customer outcomes. The Academy of Management Journal, 47(1), 41-58. https://doi.org/10.2307/20159559

Loeppke, R., Taitel, M., Haufle, V., Parry, T., Kessler, R.C., \& Jinnett, K. (2009). Health and productivity as a business strategy: A multiemployer study. Journal of Occupational and Environmental Medicine, 51(4), 411-428. https://doi. org/10.1097/JOM.0b013e3181a39180

Luria, G. (2009). The social aspects of safety management: Trust and safety climate. Accident Analysis and Prevention, 42(4), 1288-1295. https://doi.org/10.1016/j. aap.2010.02.006

Maas, C.J.M., \& Hox, J.J. (2005). Sufficient sample sizes for multilevel modelling. Methodology: European Journal of Research Methods for the Behavioural and Social Sciences, 1(3), 86-92. https://doi.org/10.1027/1614-2241.1.3.86 and https://doi.org/10.1027/1614-2241.1.3.85

MacKinnon, D.P., Lockwood, C.M., \& Williams, J. (2004). Confidence limits for the indirect effect: Distribution of the product and resampling methods. Multivariate Behavioral Research, 39(1), 99-128. https://doi.org/10.1207/ s15327906mbr3901_4

Maslach, C., Schaufeli, W.B., \& Leiter, M.P. (2001). Job burnout. Annual Review of Psychology, 52(1), 397-422. https://doi.org/10.1146/annurev.psych.52.1.397

Mathieu, J.E., \& Taylor, S.R. (2007). A framework for testing meso-mediational relationships in organizational behaviour. Journal of Organizational Behavior, 28(2), 141-172. https://doi.org/10.1002/job.436

Mattke, S., Balakrishnan, A., Bergamo, G., \& Newberry, S.J. (2007). A review of methods to measure health-related productivity loss. American Journal of Managed Care, 13(4), 211-217. 
Mayer, R.C., \& Gavin, M.B. (2005). Trust in management and performance: Who minds the shop while the employees watch the boss? Academy of Management Journal, 48(5), 874-888. https://doi.org/10.5465/AMJ.2005.18803928

McCauley, D.P., \& Kuhnert, K.W. (1992). A theoretical review and empirical investigation of employee trust in management. Public Administration Quarterly, 16(2), 265284.

Nielsen, K., Yarker, J., Randall, R., \& Munir, F. (2009). The mediating effects of team and self-efficacy on the relationship between transformational leadership, and job satisfaction and psychological well-being in healthcare professionals: A crosssectional questionnaire survey. International Journal of Nursing Studies, 46(9), 1236-1244. https://doi.org/10.1016/j.ijnurstu.2009.03.001

Owens, B.P., Baker, W.E., Sumpter, D.M., \& Cameron, K.S. (2015). Relational energy at work: Implications for job engagement and job performance. Journal of Applied Psychology, 101(1), 35-49. https://doi.org/10.1037/ap10000032

Panatik, S.A.B. (2012). Impact of work design on employee psychological strain among Malaysian technical workers. Procedia-Social and Behavioural Sciences, 40, 404-409. https://doi.org/10.1016/j.sbspro.2012.03.207

Parks, C.D., \& Hulbert, L.G. (1995). High and low trusters' responses to fear in a payoff matrix. Journal of Conflict Resolution, 39(4), 718-730. https://doi. org $/ 10.1177 / 0022002795039004006$

Pejtersen, J.H., Kristensen, T.S., Borg, V., \& Bjorner, J.B. (2010). The second version of the Copenhagen Psychosocial Questionnaire. Scandinavian Journal of Public Health, 38(3 Suppl), 8-24. https://doi.org/10.1177/1403494809349858

Pierce, J.L., O'Driscoll, M.P., \& Coghlan, A. (2004). Work environment structure and psychological ownership: The mediating effects of control. Journal of Social Psychology, 144(5), 507-534. https://doi.org/10.3200/SOCP.144.5.507-534

Poon, J.M.L. (2006). Trust-in-supervisor and helping co-workers: Moderating effects of perceived politics. Journal of Managerial Psychology, 21(6), 518-532. https:// doi.org/10.1108/02683940610684373

Rich, B.L., Lepine, J.A., \& Crawford, E.R. (2010). Job engagement: Antecedents and effects on job performance. Academy of Management Journal, 53(3), 617-635. https://doi.org/10.5465/AMJ.2010.51468988

Rich, G.A. (1997). The sales manager as a role model: Effects on trust, job satisfaction, and performance of salespeople. Journal of the Academy of Marketing Science, 25(4), 319-328. https://doi.org/10.1177/0092070397254004

Richardson, H.A., Yang, J., Vandenberg, R.J., DeJoy, D.M., \& Wilson, M.G. (2008). Perceived organizational support's role in stressor-strain relationships. Journal of Managerial Psychology, 23(7), 789-810. https://doi.org/10.1108/02683940810896349

Roslan, N., Ho, J., Ng, S., \& Sambasivan, M. (2015). Job demands \& job resources: Predicting burnout and work engagement among teachers. International Proceedings of Economics Development and Research, 84, 138-145.

Salanova, M., Agut, S., \& Peiro, J.M. (2005). Linking organizational resources and work engagement to employee performance and customer loyalty: The mediation of service climate. Journal of Applied Psychology, 90(6), 1217-1227. https://doi. org/10.1037/0021-9010.90.6.1217 
Schaufeli, W.B., \& Bakker, A.B. (2004). Job demands, job resources, and their relationship with burnout and engagement: A multi-sample study. Journal of Organizational Behavior, 25(3), 293-315. https://doi.org/10.1002/job.248

Schaufeli, W.B., Bakker, A.B., \& Van Rhenen, W.V. (2009). How changes in job demands and resources predict burnout, work engagement, and sickness absenteeism. Journal of Organizational Behavior, 30(7), 893-917. https://doi.org/10.1002/ job. 595

Schaufeli, W.B., Bakker,A.B., \& Salanova,M.(2006). The measurement of work engagement with a short questionnaire a cross-national study. Educational and Psychological Measurement, 66(4), 701-716. https://doi.org/10.1177/0013164405282471

Schaufeli, W.B., Salanova,M., Gonzalez-Roma, V., \& Bakker,A.B. (2002). The measurement of engagement and burnout: A confirmative analytic approach. Journal of Happiness Studies, 3(1), 71-92. https://doi.org/10.1023/A:1015630930326

Scott, W.R. (1995). Institutions and organizations: Ideas, interests, and identities. Thousand Oaks, CA: Sage.

Selig, J.P., \& Preacher, K.J. (2008). Monte Carlo method for assessing mediation: An interactive tool for creating confidence intervals for indirect effects [computer software]. Available from http://quantpsy.org/.

Shafie, H.B. (1996). Malaysia's experience in implementing the new performance appraisal system. Public Administration and Development, 16(4), 341-352. https://doi. org/10.1002/(SICI)1099-162X(199610)16:4<341::AID-PAD886>3.0.CO;2-N

Shelton, S.T. (2002). Employee, supervisors and empowerment in the public sector: The role of employee trust. PhD dissertation, North Carolina State University.

Sprigg, C.A., Jackson, P.R., \& Parker, S.K. (2000). Production teamworking: The importance of interdependence and autonomy for employee strain and satisfaction. Human Relations, 53(11), 1519-1543. https://doi.org/10.1177/00187267005311005

Tansky, J.W., \& Cohen, D.J. (2001). The relationship between organizational support, employee development, and organizational commitment: An empirical study. Human Resource Development Quarterly, 12(3), 285-300. https://doi. org $/ 10.1002 /$ hrdq. 15

Taris, T.W., \& Schreurs, P.J.G. (2009). Well-being and organizational performance: An organizational level test of the happy-productive worker hypothesis. Work and Stress, 23(2), 120-136. https://doi.org/10.1080/02678370903072555

Teare, R., Cummings, W., Donaldson-Brown, M.A., \& Spittle, H. (2011). The role of action learning in personal, professional and business development. Worldwide Hospitality and Tourism Themes, 3(1), 60-65. https://doi.org/10.1108/17554211111104952

Trépanier, S.G., Fernet, C., Austin, S., Forest, J., \& Vallerand, R.J. (2014). Linking job demands and resources to burnout and work engagement: Does passion underlie these differential relationships? Motivation and Emotion, 38(3), 353-366. https:// doi.org/10.1007/s11031-013-9384-Z

Tuckey, M.R., Bakker, A.B., \& Dollard, M.F. (2012). Empowering leaders optimize working conditions for engagement: A multilevel study. Journal of Occupational Health Psychology, 17(1), 15-27. https://doi.org/10.1037/a0025942 
Tzafrir, S.S., \& Dolan, S.L. (2004). Trust me: A scale for measuring manager-employee trust. Management Research: Journal of the Iberoamerican Academy of Management, 2(2), 115-132. https://doi.org/10.1108/15365430480000505

Wang, H., Hall, N.C., \& Rahimi, S. (2015). Self-efficacy and casual attributions in teachers: Effects on burnout, job satisfaction, illness, and quitting intentions. Teaching and Teacher Education, 47, 120-130. https://doi.org/10.1016/j.tate.2014.12.005

Westin, A.F. (2003). Two key factors that belong in a macroergonomic analysis of electronic monitoring: Employee perceptions of fairness and the climate of organizational trust or distrust. Applied Ergonomics, 23(1), 35-42. https://doi.org/10.1016/00036870(92)90008-J

Wilson, M.G., DeJoy, D.M., Vandenberg, R.J., Richardson, H.A., \& McGrath, A.L. (2004). Work characteristics and employee health and well-being: Test of a model of healthy work organization. Journal of Occupational and Organizational Psychology, 77(4), 565-588. https://doi.org/10.1348/0963179042596522

World Economic Forum. (2015). The Global Competitiveness Report 2015-2016. Retrieved 13 February 2016 from http://www3.weforum.org/docs/gcr/20152016/Global_Competitiveness_Report_2015-2016.pdf

Zapata, C.P., Olsen, J.E., \& Martins, L.L. (2013). Social exchange from the supervisor's perspective: Employee trustworthiness as a predictor of interpersonal and informational justice. Organizational Behavior and Human Decision Processes, 121(1), 1-12. https://doi.org/10.1016/j.obhdp.2012.11.001

Zapf, D., Dormann, C., \& Frese, M. (1996). Longitudinal studies in organizational stress research: A review of the literature with reference to methodological issues. Journal of Occupational Health Psychology, 1(2), 145-169. https://doi. org/10.1037/1076-8998.1.2.145

Zhang, X.M., \& Zhou, J. (2014). Empowering leadership, uncertainty avoidance, trust, and employee creativity: Interaction effects and a mediating mechanism. Organizational Behavior and Human Decision Processes, 124(2), 150-164. https://doi.org/10.1016/j.obhdp.2014.02.002 